\title{
PERFORMA PADA MOTOR BAKAR 6-LANGKAH DENGAN LANGKAH POWER EKSPANSI SAMPAI TITIK MATI BAWAH
}

\author{
Riswan Sepriyatno \\ Mahasiswa S2 \\ Universitas Brawijaya \\ Jurusan Teknik Mesin \\ Email: \\ riswansepriyatno@ymail.com \\ Eko Siswanto \\ Tenaga Pengajar (Dosen) \\ Universitas Brawijaya \\ Jurusan Teknik Mesin \\ Email: \\ Eko_s112@ub.ac.id
Tenaga Pengajar (Dosen) Universitas Brawijaya Jurusan Teknik Mesin Email: hamidy@ub.ac.id \\ Nurkholis Hamidi
}

This study aims are to observe the performance of a six-stroke combustion motor and to analyze the thermodynamics of a six-stroke combustion engine with a power expansion step to the bottom dead center. The fuel used in this observation is pertalite with a RON 90 value. The method used is a true experimental method, with independent variables, namely 35\%, 40\%, 45\%, and 50\% throttle openings with loading on the prony disc brake of $10 \mathrm{~kg}, 20 \mathrm{~kg}, 30 \mathrm{~kg}$, $40 \mathrm{~kg}$, and 50kg. In the torque data, each throttle opening shows the highest number of $7.26(\mathrm{Nm})$ with a load of $50 \mathrm{~kg}$ and the lowest value of $2.01(\mathrm{Nm})$ with a load of $10 \mathrm{~kg}$, for effective power the highest value is $8.47(\mathrm{~kW})$ at $50 \%$ throttle opening with load is $40 \mathrm{~kg}$ and the lowest value is $2.49(\mathrm{~kW})$ at 35\% throttle opening with a load of $10 \mathrm{~kg}$, while for the specific fuel consumption (SFC) the highest value is $4.28(\mathrm{~kg} / \mathrm{Hp} . \mathrm{h})$ at $40 \%$ throttle opening with a load of $10 \mathrm{~kg}$ and the lowest value is 0.77 ( $\mathrm{kg} / \mathrm{Hp} . \mathrm{h})$ at $50 \%$ throttle openings with a load of $50 \mathrm{~kg}$, and for the thermal efficiency of the six-stroke motor, which means an average increase of $14.58 \%$ compared to the thermal efficiency of the conventional 4-stroke internal combustion engine.

Keywords: Thermodynamics, Expansion to TMB, Thermal Efficiency

\section{PENDAHULUAN}

Teknologi transportasi kendaraan bermotor di era modern saat ini mengalami perkembangan, berdasarkan dari data survei Badan Pusat Statistik Indonesia yaitu jumlah kendaraan bermotor pertahun 2018 total semua mencapai 146.858.760 unit [1]. Pencemaran udara yang dihasilkan oleh kendaraan bermotor transportasi memiliki presentase tertinggi mencapai $70 \%$, untuk sektor industri memiliki persentase sebesar $25 \%$, dan sampah memiliki pencemaran terendah sebesar 5\% [2].

Jenis kendaraan bermotor saat ini yang banyak digunakan adalah jenis motor 2-langkah dan 4langkah. Namun terdapat kerugian pada kendaraan bermotor jenis 2-langkah yaitu pada konsumsi bahan bakar yang tinggi yang mengakibatkan emisi gas buang meningkat serta suara yang bising, hal ini membuat produksi motor bakar 2-langkah tidak diproduksi lagi diberbagai sektor industri, berbanding balik dengan kendaran bermotor jenis 4-langkah memiliki keunggulan yaitu konsumsi bahan bakar yang irit dan rendah emisi gas buang serta suara yang yang di hasilkan motor bakar 4-langkah halus [3,4].

Agar performa motor bakar menjadi lebih efisien serta memiliki daya tinggi maka penelitian terus dilakukan. Penelitian pada motor bakar 4 langkah yang menggunakan siklus Otto memiliki kelemahan efisiensi dan daya yang dihasilkan terbatas [5]. Salah satu penyebab terjadinya (losses) ialah terbukanya exhaust valve terlalu awal, sehingga tekanan working-gas yang masih tinggi dibuang sia-sia, yang sebenarnya masih dapat digunakan untuk memperpanjang langkah sampai TMB. Jadi dapat disimpulkan siklus Otto 4langkah aktual memiliki ekspansi rasio yang lebih rendah daripada kompresi rasionya[6], seperti pada Gambar 1(a). Untuk meningkatkan efisiensi motor bakar 4-langkah tersebut, kemudian Atkinson mengusulkan sebuah siklus termodinamika yang memiliki ekspansi rasio yang lebih besar terhadap kompresi rasionya. Akan tetapi pada panjang stroke yang sama dengan Otto, siklus Atkinson meskipun memiliki efisiensi yang tinggi tetapi memiliki power output yang rendah [7]. Siklus Atkinson ditunjukan pada Gambar 1(b). Kemudian siklus motor bakar 6-langkah tipe-5 menggunakan siklus MUB-5 dapat dilihat pada Gambar 2. 


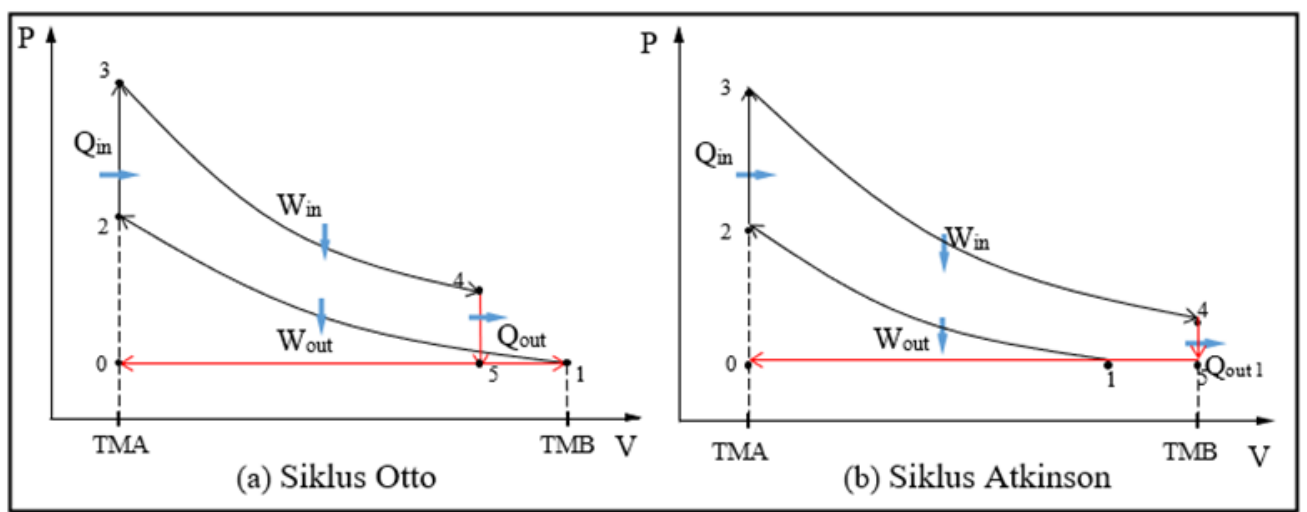

Gambar 1: Siklus aktual (a) Siklus Otto 4-langkah, (b) Siklus Atkinson 4-langkah

Adapun proses dari siklus aktual motor bakar 6-langkah tipe-5 menggunakan siklus MUB-5 yaitu:

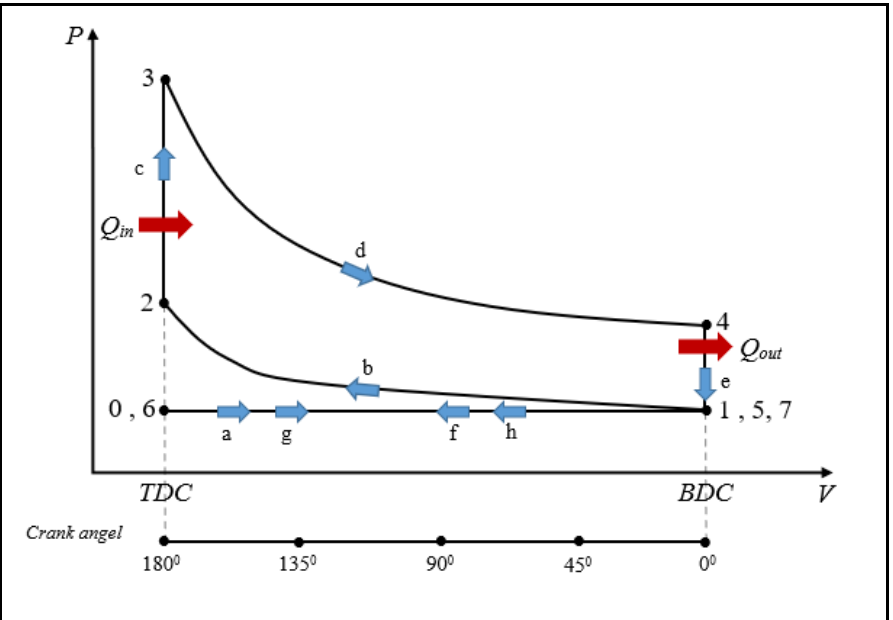

1. (0-1) Intake (Isobaric)

2. (1-2) Compression (Isentropic) (2-3) Heat input (Isochoric)

3. (3-4) Expansion (Isentropic)

4. (4-5) Exhaust (Isochoric)

(5-6) Pengurangan volume (Isobaric)

5. (6-7) Penambahan volume (Isobaric)

6. (7-0) Pengurangan volume (Isobaric)

Gambar 2. Siklus aktual motor bakar 6-langkah tipe -5 menggunakan siklus MUB-5

Untuk itu penelitian ini bertujuan untuk mengembangkan teknologi motor bakar 4-langkah ke 6langkah dengan menggabungkan kedua siklus yaitu siklus Otto dan siklus Atkinson menjadi sebuah siklus yang akan diterapkan pada motor bakar 6-langkah tipe-5, yang kemudian disebut dengan siklus MUB-5. Siklus ini dapat meningkatkan power yang sama dengan siklus Otto dan efisiensinya sama dengan siklus Atkinson. Konsep terbaru yang dihadirkan dari penelitian ini yaitu dengan menggubah pergerakan piston hingga sampai TMB pada langkah buang sehingga menghasilkan power yang lebih maksimal. Perbandingan motor 4-langkah siklus Otto yang terbuka exhaust-valve nya sekitar $45^{\circ}$ sebelum TMB dan motor bakar 6langkah tipe-5 menggunakan siklus MUB-5 (exhaust-valve terbuka saat di TMB) dapat dilihat pada Gambar 3.

Motor bakar 6-langkah telah dikembangkan oleh Bajulaz Engine [8], dan the M4+2 Engine [9], Bazmi Engine [10]. Masing-masing memiliki konstruksi dan mekanisme yang berbeda tetapi dengan tujuan yang sama yaitu untuk meningkatkan efisiensi dan mengurangi emisi gas buang.

Siswanto et al [11,12] melakukan penelitian motor bakar 6-langkah dari mesin motor 4-langkah buatan Honda berkapasitas $125 \mathrm{cc}$ yang mana telah diubah konstrusi mesinya sehingga menjadi motor bakar 6-langkah tipe-1 menggunakan siklus MUB-1. Penambahan 2-langkah pada motor bakar 6-langkah ini yaitu langkah ekspansi mixing dan langkah kompresi mixing. Penelitian ini dipengaruhi pada diameter venturi yaitu $18(\mathrm{~mm})$ dan $20(\mathrm{~mm})$ yang diaplikasikan untuk mesin 4-langkah dan 6-langkah. Pada motor bakar 6-langkah tipe 1 menggunakan siklus MUB-1, dengan alasan jika dibandingkan dengan motor bakar 4-langkah, motor bakar 6-langkah menghasilkan bahan bakar yang lebih irit dan mengurangi emisi gas buang. Engine ini memiliki tambahan dua langkah mixing pada setiap siklus sebelum terjadi proses pembakaran/ignition untuk menjadikan campuran antara bahan bakar dan udara semakin homogen. 


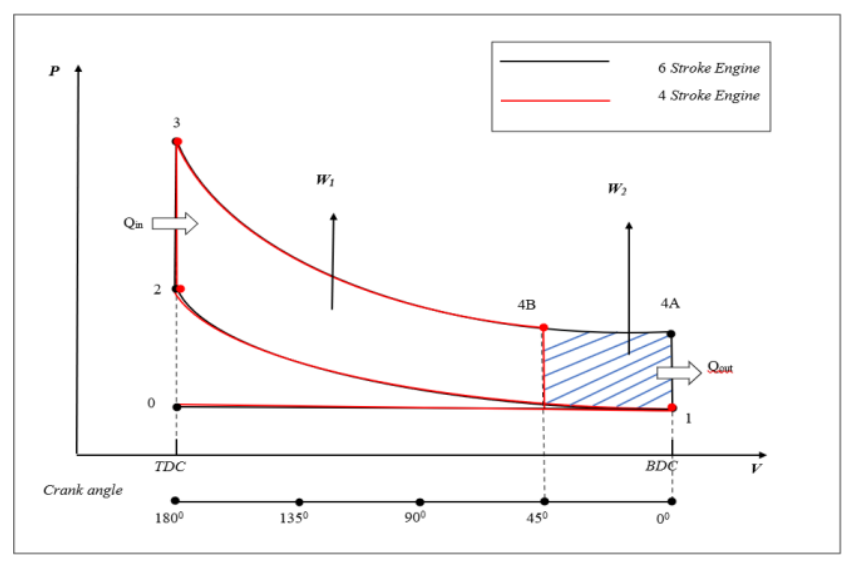

Gambar 3. Perbandingan p-v diagram motor bakar 6-langkah tipe-5 dengan siklus MUB-5 (exhaust-valve terbuka di TMB) dan motor bakar 4-langkah dengan siklus Otto actual (exhaust-valve terbuka $45^{\circ}$ sebelum TMB).

Kemudian pada tahun 2017 Siswanto et al [13] telah mengembangkan motor bakar 6-langkah tipe-2 menggunakan siklus MUB-2 dimana penelitian ini membandingkan ICE (Internal Combustion Engine) motor bakar 4-langkah dengan motor bakar 6-langkah tipe 2 menggunakan siklus MUB-2. Konsep motor bakar 6-langkah ini mempunyai penambahan langkah ekspansi dan langkah kompresi disertai proses pembakaran lanjut setelah proses pembakaran yang pertama. Kompresi kedua merekompresi kembali combustible species yang belum terbakar saat pembakaran pertama, kemudian membakar kembali sehingga didapatkan kalor tambahan ( $Q$ in). Kedua generasi tersebut menghasilkan tenaga yang lebih besar dan emisi gas buang yang sedikit. Dapat disimpulkan bahwa konsep motor bakar 6-langkah tersebut memiliki potensi yang besar untuk dikembangkan sebagai suatu alternatif baru teknologi motor bakar dimasa depan yang ramah lingkungan.

Berdasarkan uraian diatas, dapat diambil hipotesis yaitu jika motor bakar 6-langkah tipe-5 menggunakan siklus MUB-5 (atau, awal kompresi sama dengan Otto tetapi langkah ekspansi-power sampai TMB), maka akan didapatkan power yang lebih tinggi daripada motor Atkinson dan efisiensi yang lebih tinggi dari motor Otto actual.

\section{METODE DAN BAHAN}

Penelitian ini menggunakan motor bakar 4-langkah yang telah modifikasi sedemikian rupa sehingga menjadi motor bakar 6-langkah. Pengaturan modifikasi pada penelitian ini dilakukan dengan cara memberikan gigi reduksi dan penambahan rantai kamrat di antara putaran camshaft dengan putaran crankshaft. Dengan demikian putaran crankshaft terjadi tiga kali sedangkan putaran camshaft terjadi satu kali. Selain itu ada perubahan pada bentuk model camshaft, yang nantinya mengatur pada saat katup hisap membuka pada posisi piston berada di TMA dan menutup pada posisi piston di TMB untuk katup buang akan terbuka dimana posisi piston berada di TMB dan menup sampai durasi nok camshaft habis atau posisi piston berada di TMA.

\subsection{Instalasi Penelitian}

Dalam penelitian ini, metode yang digunakan adalah metode eksperimental nyata, dimana penelitian dilakukan secara langsung terhadap objek yang akan diuji. Pengamatan dilakukan secara langsung untuk mengetahui bagaimana performa torsi, daya efektif, konsumsi bahan bakar spesifik (SFCe), dan efisiensi termal, pada motor bakar 6-langkah tipe-5 menggunakan siklus MUB-5 dengan langkah power sampai TMB menggunakan bahan bakar minyak Pertalite/RON 90.

Variabel penelitian ini terdiri dari variabel bebas yaitu: bukaan Throttle sebesar 35\%, 40\%, 45\%, $50 \%$. Dan pembebanan pada Prony Disc Brake sebesar 10kg, 20kg, 30kg, 40kg, 50kg. Variabel terikat pada penelitian ini yaitu: torsi, daya efektif (Ne), konsumsi bahan bakar (FC), efisiensi termal. Variabel terkontrol pada penelitian ini antara lain: bahan bakar yang digunakan adalah bahan bakar cair Pertalite dengan nilai RON 90, pengujian menggunakan karburator jenis PE 28, motor bakar 6-langkah tipe-5 dengan kapasitas mesin 125 cc yang diteliti pada kondisi modifikasi dari motor bakar 4-langkah, dan rasio kompresi mesin sebesar $9: 1$. 


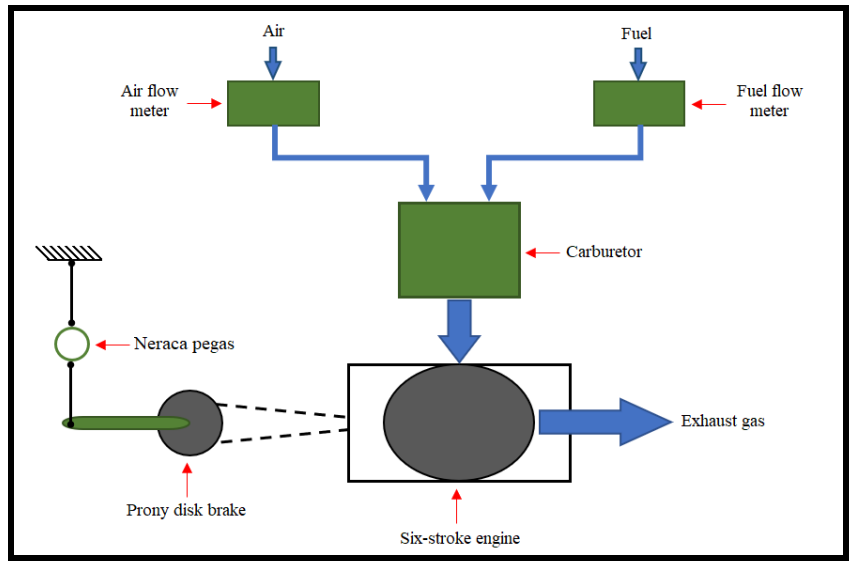

Gambar 4. Instalasi penelitian.

Prosedur pengambilan data dari penelitian ini diantaranya mempersiapkan instalasi mesin kemudian memasukkan bahan bakar Pertalite ke dalam tangki bahan bakar dilanjutkan menyalakan mesin menggunakan starter dan biarkan mesin beroperasi pada kondisi idle untuk beberapa saat hingga kondisi mesin stabil dan menyalakan blower sebagai pembantu media pendinginan mesin.

Cara pengambilan data yang perlu dilakukan sebagai berikut: (1) Atur bukaan throttle yang pertama pada bukaan $35 \%$. (2) Lakukan pengereman dimulai dari berat beban $10 \mathrm{~kg}, 20 \mathrm{~kg}, 30 \mathrm{~kg}, 40 \mathrm{~kg}, 50 \mathrm{~kg}$, dan diamkan beberapa saat hingga kondisi mesin stabil. (3) Diamkan selama beberapa saat pada setiap variasi beban pengereman untuk menstabilkan mesin. (4) Lakukan pengambilan data (beban pada prony disc brake, waktu konsumsi bahan bakar, rpm). (5) Ulangi langkah 1-4 untuk variasi bukaan throttle pada bukaan 40\%, 45\%, dan 50\% hingga putaran mesin pada crankshaft terendah $2400 \mathrm{rpm}$ sampai tertinggi $21600 \mathrm{rpm}$.

Adapun bahan yang digunakan dalam penelitian ini yaitu menggunakan bahan bakar Pertalite RON 90. Keunggulan Pertalite versi pertamina antara lain Pertalite dinilai lebih bersih daripada Premium karena memiliki Research Octant Number (RON) di atas 88 yang terkandung dalam Premium [14].

\subsection{Perhitungan Torsi, Daya efektif, Konsumsi bahan bakar spesifik dan Efisiensi termal}

Untuk mengetahui besarnya daya efektif, perlu di ketahui besar torsi crankshaft terlebih dahulu. Torsi dapat di hitung dari nilai torsi disc brake (Td). Torsi disc brake (Td) dapat dihitung dengan persamaan 1.

$$
\mathrm{Td}=[(\mathrm{F} \times \mathrm{L})+(\mathrm{f} \times \mathrm{l})] \times 9,8(\mathrm{~N} . \mathrm{m})
$$

Dimana $\mathrm{F}$ adalah beban penegereman $(\mathrm{kg}), \mathrm{L}$ adalah panjang lengan beban $(\mathrm{m})$, f adalah berat dari disc brake $(\mathrm{kg})$, I adalah jarak kaliper pengereman menuju titik pusat disc brake (m). Sehingga besar torsi crankshaft diperoleh dari persamaan 2 .

$$
\mathrm{Tc}=\frac{\mathrm{Td}}{\mathrm{i}_{\mathrm{n}}}(\mathrm{N} \cdot \mathrm{m})
$$

Dimana $\hat{l}_{n}$ adalah rasio dari gear transmisi. Daya efektif dari motor bakar 6-langkah dapat dihitung dengan menggunakan persamaan 3 .

$$
\mathrm{Ne}=\frac{2 \pi \times \mathrm{Tc} \times \mathrm{N}}{60 \times 1000}(\mathrm{~kW})
$$

Tc merupakan besar nilai torsi pada cranshaft dan $\mathrm{N}$ adalah kecepatan putaran dari cranshaft. Konsumsi bahan bakar (FC) merupakan massa dari bahan bakar (kg) yang dikonsumsi oleh mesin dalam satuan waktu (jam) persamaan 4.

$$
\mathrm{SFCe}=\frac{\mathrm{FC}}{\mathrm{Ne}}(\mathrm{kg} / \mathrm{kW} \cdot \mathrm{h})
$$

FC merupakan jumlah konsumsi bahan bakar dari motor bakar (kg/jam) dan Ne merupakan besar daya efektif yang dihasilkan oleh motor bakar $(\mathrm{kW})$. Efisiensi termal dihitung menggunakan persamaan 5 .

$$
\eta_{t}=\left[\frac{\text { Qout }- \text { Qin }}{\text { Qin }}\right] \times 100 \%
$$




\section{HASIL DAN DISKUSI}

\subsection{Hubungan antara Putaran Mesin yang diberi Pembebanan dengan Torsi (TC) pada Motor Bakar 6-} Langkah Tipe-5.

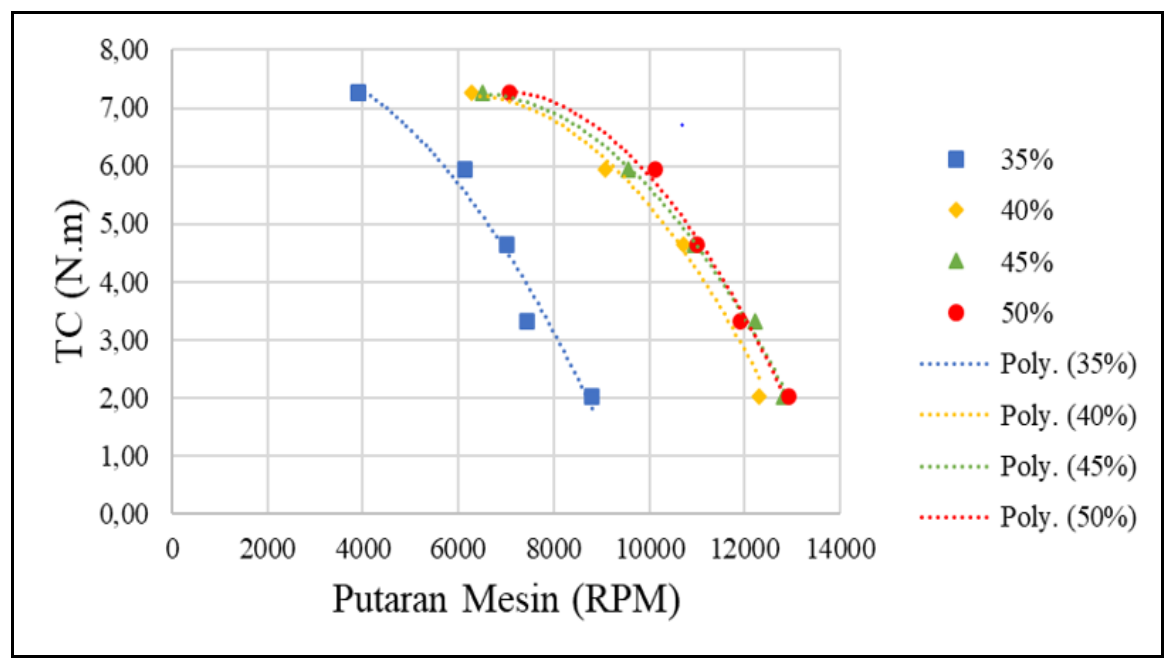

Gambar 5: Grafik crank torsion (TC) dengan bukaan throtlle sebesar 35\%, 40\%, 45\%, dan 50\%, dengan pembebanan 10 $\mathrm{kg}, 20 \mathrm{~kg}, 30 \mathrm{~kg}, 40 \mathrm{~kg}$, dan $50 \mathrm{~kg}$.

Semakin besar bukaan throtlle maka semakin tinggi torsi yang diperoleh namun rpm semakin menurun (Gambar 5). Dikarenakan pada saat pengujian dimulai dari putaran tertinggi setiap bukaan throtlle lalu diturunkan dengan penambahan beban pengereman pada poros. Sehingga menyebabkan putaran mesin (rpm) menurun namun torsi yang dihasilkan meningkat (grafik dilihat dari rpm tertinggi/dari sebelah kanan). Menurunya putaran mesin (rpm) tidak mempengaruhi torsi yang dihasilkan melainkan torsi yang didapatkan semakin meningkat. Hal ini dikarenakan langkah ekspansi pada motor bakar 6-langkah tipe-5 yang diubah mencapai TMB sehingga menyebabkan bahan bakar terkompresi cukup tinggi yang dapat minimbulkan ledakan bahan bakar dan udara mendekati sempurna, dan menghasilkan gaya dorong yang lebih besar pada piston yang menyebabkan torsi yang dihasilkan menjadi lebih besar. Pada bukaan throtlle 35\% rpm relatif menurun secara konstan hal ini didapati rpm pada bukaan throtlle 35\% memiliki putaran mesin sebesar 8.000 rpm yang kemudian diberikan beban sehingga menurun lebih konstan dari pada bukaan throttle $40 \%, 45 \%$, dan $50 \%$ yang diawal putaran mesinya sudah mencapai $1.200 \mathrm{rpm}$.

Gambar 5 menunjukkan grafik crank torsion (Tc) pada bukaan throttle 35\%, 40\%, 45\%, dan $45 \%$. Dari grafik tersebut dapat disimpulkan bahwa torsi terendah sebesar 2,01 N.m dengan putaran mesin sebesar $12.927 \mathrm{rpm}$ pada bukaan throtlle $50 \%$ dengan pembebanan $10 \mathrm{~kg}$, dan torsi tertinggi sebesar 7,26 N.m dengan putaran mesin sebesar $3.927 \mathrm{rpm}$. Dengan menurunya putaran mesin (rpm) namun pada motor bakar 6-langkah tipe-5 torsi yang didapatkan meningkat, menigkatnya torsi pada motor bakar 6-langkah tipe-5 karena langkah ekspasi pada piston diubah sampai TMB.

\subsection{Hubungan antara Putaran Mesin yang diberi Pembebanan Dengan Daya Efektif (Ne) Motor Bakar 6-Langkah Tipe-5}

Pada grafik dijelaskan semakin besar beban yang diberikan pada putaran mesin (rpm) daya efektif yang didapatkan meningkat (Gambar 6). Namun pada setiap bukaan thortlle dengan pembebanan 50\% daya efektif cenderung menurun. Pada gambar 6 dapat disimpulkan bahwa daya efektif terendah yaitu $2,49 \mathrm{~kW}$ pada bukaan throttle $35 \%$ dengan pembebanan $10 \mathrm{~kg}$ dan daya efektif tertinggi yaitu $8,47 \mathrm{~kW}$ pada bukaan throttle $50 \%$ dengan pembebanan $40 \mathrm{~kg}$.

Daya efektif yang dihasilkan mengalami kenaikan seiring dengan bukaan throttle yang semakin besar hal ini dikarenakan campuran udara dan bahan bakar dalam ruang bakar masih dalam fase dimana reaksi pembakaran optimal sehingga masih memungkinkan piston melakukan langkah usaha, seiring dengan kenaikan daya efektif pada titik tertentu akan mengalami penurunan. Setelah melewati fase optimal daya efektif pada bukaan throttle 35\%, 40\%, 45\% dan 50\% dengan pembebanan 50kg daya efektif cenderung mengalami penurunan secara konstan karena pembebanan yang terlalu besar sehingga putaran mesin (rpm) menurun sangat signifikan menyebabakan mesin tidak setabil, tidak stabilnya putaran mesin kemungkinan 
pembakaran bahan bakar didalam ruang bakar tidak optimal menyebabkan pergerakan piston saat melakukan langkah usaha tidak maksimal, hal ini lah yang menyebabkan daya efektif mengalami penurunan pada titik tertentu.

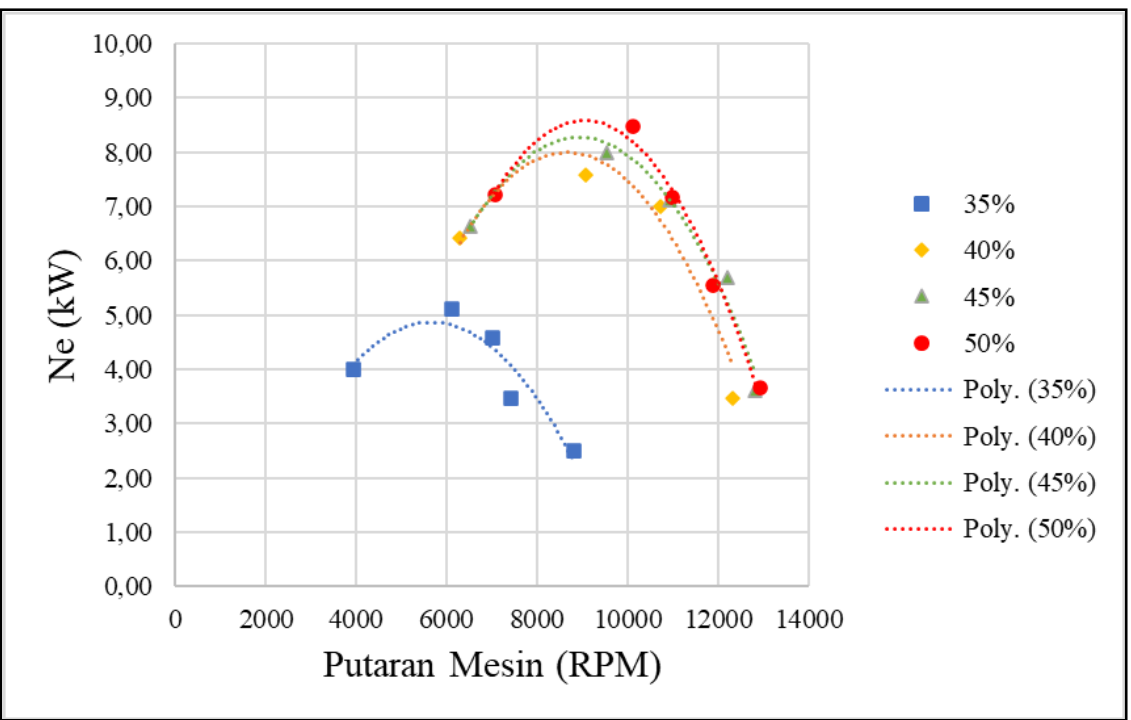

Gambar 6: Grafik daya efektif (Ne) dengan bukaan throtlle sebesar 35\%, 40\%, 45\%, dan 50\%, dengan pembebanan 10 $\mathrm{kg}, 20 \mathrm{~kg}, 30 \mathrm{~kg}, 40 \mathrm{~kg}$, dan $50 \mathrm{~kg}$.

\subsection{Hubungan antara Putaran Mesin yang diberi Pembebanan dengan Konsumsi Bahan Bakar Spesifik (SFCe) Motor Bakar 6-Langkah Tipe-5}

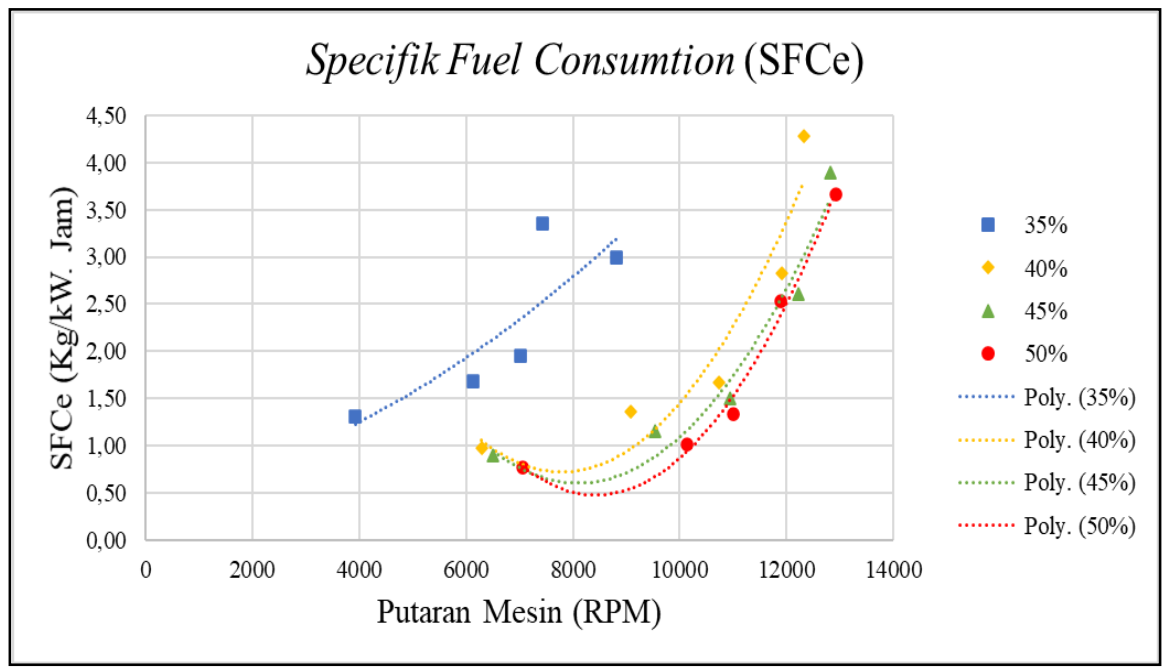

Gambar 7: Grafik Konsumsi bahan bakar spesifik SFCe (kg/kW.jam) dengan bukaan throtlle sebesar 35\%, 40\%, 45\%, dan $50 \%$, dengan pembebanan $10 \mathrm{~kg}, 20 \mathrm{~kg}, 30 \mathrm{~kg}, 40 \mathrm{~kg}$, dan $50 \mathrm{~kg}$.

Grafik konsumsi bahan bakar spesifik per $10 \mathrm{ml}$ pada bukaan throttle 35\%, 40\%, 45\% dan 50\% dengan pembebanan $10 \mathrm{~kg}-50 \mathrm{~kg}$ dengan interval $10 \mathrm{~kg}$. Pada grafik tersebut dilihat semakin besar beban yang di berikan menunjukkan grafik konsumsi bahan bakar spesifik (SFCe) menurun (gambar 7). setiap bukaan throttle yang dipengaruhi pembebanan membuat putaran mesin (rpm) juga semakin menurun, pada grafik menunjukkan semakin rendah putaran mesin (rpm) maka konsumsi bahan bakar spesifik (SFCe) yang dihasilkan juga semakin menurun. Namun Pada bukaan throttle 35\% dengan beban yang diberikan sebesar 10kg memiliki putaran mesin $8.808 \mathrm{rpm}$ dengan konsumsi bahan bakar sebesar 2,99 kg/Kw.jam lebih rendah dibandingkan pada bukaan throttle $35 \%$ beban yang diberikan sebesar 20kg memiliki putaran mesin 7.434 rpm dengan konsumsi bahan bakar sebesar $3,35 \mathrm{~kg} / \mathrm{kW}$.jam, dengan menurunnya putaran mesin (rpm) membuat durasi membuka dan menutupnya katup intake pelan hal ini lah yang membuat bahan bakar yang 
masuk ke ruang bakar semakin kaya namun jika pada rpm tinggi bahan bakar yang masuk ke dalam ruang bakar cukup. Cukupnya waktu proses difusi udara-bahan bakar akan mengikatkan homogenitas campuran sehingga proses pembakaran menjadi lebih baik, yang pada akhirnya akan menghasilkan kinerja yang lebih baik [15] bisa dikatakan konsumsi bahan bakar pada motor bakar 6-langkah pada rpm tinggi lebih irit.

Konsumsi bahan bakar spesifik paling rendah yaitu $0,77 \mathrm{~kg} / \mathrm{kW}$.jam pada bukaan throttle $50 \%$ saat putaran mesin $7.062 \mathrm{rpm}$ dan konsumsi bahan bakar spesifik tertinggi yaitu 4,28 kg/kW.jam pada bukaan throttle $40 \%$ saat putaran $12.315 \mathrm{rpm}$. Konsumsi bahan bakar spesifik rata-rata mesin 6 langkah MUB-05 yaitu $2,09(\mathrm{~kg} / \mathrm{kW} . \mathrm{jam})$.

\subsection{Efisiensi Termal Motor Bakar 4-Langkah dan Efisiensi Termal Dan Motor Bakar 6-Langkah Tipe-5 Menggunakan Siklus MUB-5}

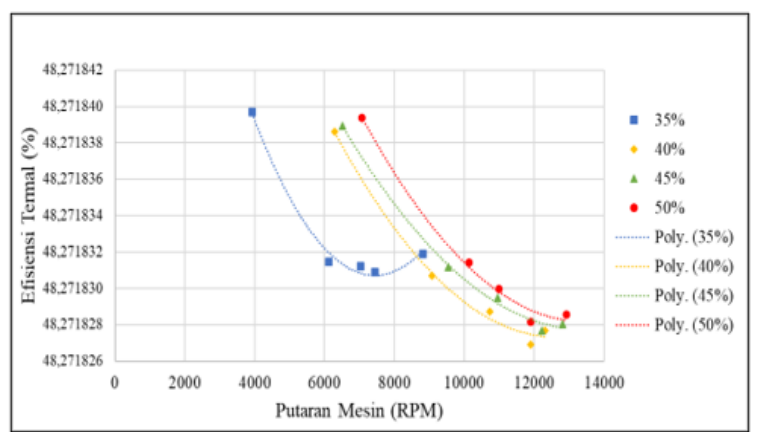

(a)

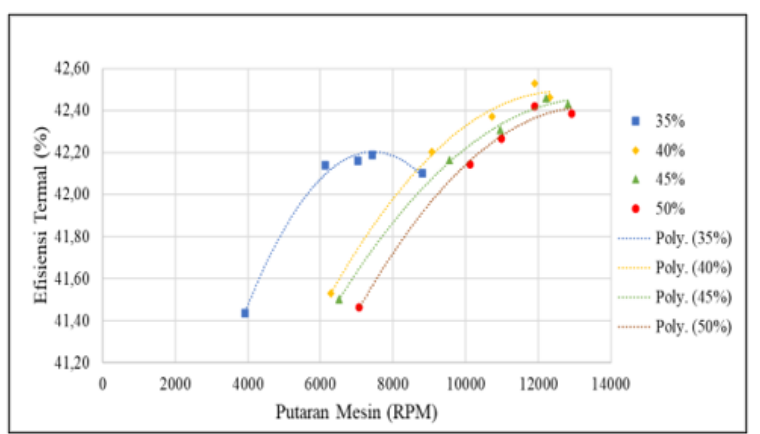

(b)

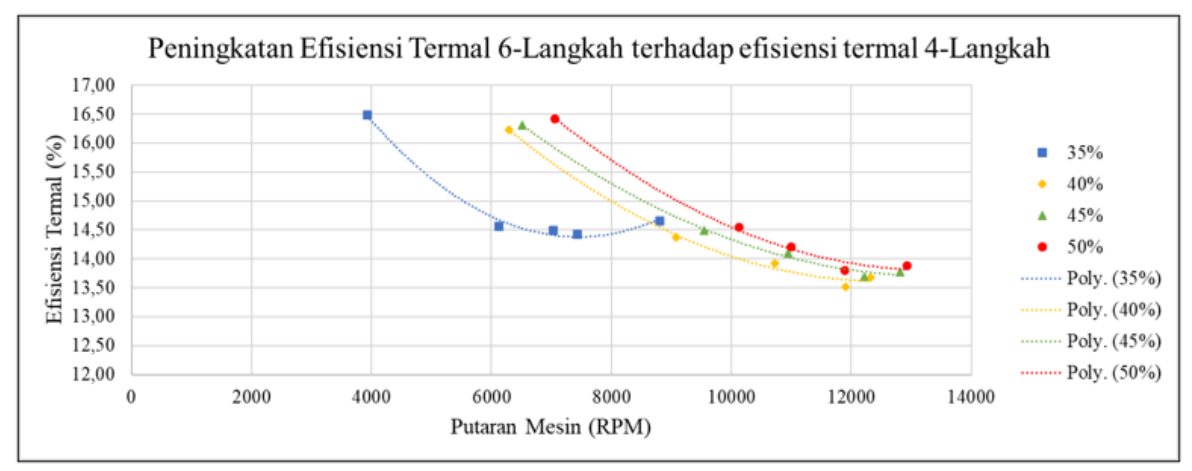

(c)

Gambar 8: Perbandingan efisiensi termal (a) motor bakar 6-langkah tipe-5 menggunkan siklus MUB-5, (b) motor bakar 4-langkah dan (c) selisih kenaikan efisiensi termal pada motor bakar 6-Langkah jika dibandingkan dengan efisiensi termal motor bakar 4-langkah.

Dari hasil perhitungan bahwa siklus MUB-5 pada motor bakar 6-langkah tipe-5 lebih tinggi dibandingkan efisiensi motor bakar 4-langkah hal ini disebabkan lagkah ekspansi pada motor bakar 6langkah tipe-5 ini sampai titik mati bawah. Dari motor bakar 6-langkah tipe-5 ini efisiensi termal mencapai 48,27\% diambil dari rata-rata sedangkan pada motor bakar 4-langkah efisiensi termal mencapai $42,13 \%$ diambil dari rata-rata. efisiensi termal pada motor bakar 6-langkah mengalami peningkatan sebsar $14,58 \%$ diambil dari rata-rata. Perhitungan siklus motor bakar 6-langkah tipe-5 menggunakan siklus MUB-5 dan siklus motor bakar 4-langkah milik Otto dapat dilihat sebagai berikut.

Hasil analisis perhitungan efisiensi termal pada bukaan throttle 35\% dengan pembebanan 10kg. Untuk luasan efisiensi thermal pada motor bakar 6-langkah tipe -5 menggunakan siklus MUB-5 sebagai berikut:

$$
\left(\eta_{t}\right)=\frac{w}{\text { Qin }}=\frac{\text { Qin-Qout }}{\text { Qin }}=1-\frac{\text { Qout }}{\text { Qin }}=1-\frac{134,1093 \mathrm{~J}}{259,29 \mathrm{~J}}=48,27 \%
$$

Untuk perhitungan luasan efisiensi termal pada motor bakar 4 langkah sebagai berikut:

$$
\left(\eta_{t}\right)=\frac{w}{\text { Qin }}=\frac{\text { Qin-Qout }}{\text { Qin }}=1-\frac{\text { Qout }}{\text { Qin }}=1-\frac{150,109 \mathrm{~J}}{259,29 \mathrm{~J}}=42,10 \%
$$

Perhitungan hasil selisih luasan antara efisiensi termal 6-langkah dan 4-langkah sebagai berikut: 


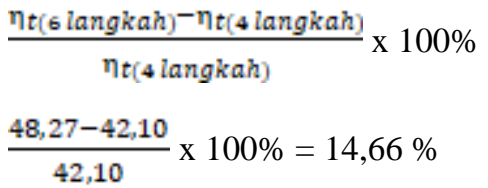

Hasil selisih perbandingan antara luasan efisiensi termal motor bakar 6-langkah tipe-5 menggunakan siklus MUB-5 dan 4-langkah terjadi kenaikan efisiensi termal pada motor bakar 6-langkah tipe-5 menggunakan siklus MUB-5 sebesar 14,66\% diambil dari sampel bukaan throtlle 35\% dengan pembebanan sebesar $10 \mathrm{~kg}$.

\section{KESIMPULAN}

Berdasarkan hasil pengambilan data menggunakan metode eksperimental yang mana pada motor bakar 6langkah tipe-5 menggunakan siklus MUB-5 langkah ekspansi sampai TMB diperoleh hasil torsi (TC) yang meningkat meskipun putaran mesin menurun sehingga daya efektif $(\mathrm{Ne})$ yang dihasilkan juga meningkat pada setiap pembebanan namun pada titik tertentu mengalami penuruan yag disebabkan beban yang diberikan pada putaran mesin melampaui batas maksimal. Kemudian terdapat nilai konsumsi bahan bakar spesifik (SFCe) terendah pada variasi bukaan throttle $50 \%$ dengan pembebanan $50 \mathrm{~kg}$, hasil nilai konsumsi bahan bakar tersebut diperoleh nilai sebesar $0,77 \mathrm{~kg} / \mathrm{kW}$.jam, sehingga dapat diasumsikan konsumsi bahan bakar yang dihasilkan lebih irit dibandingkan dengan variasi bukaan throttle dan pembebanan yang lainya. Hasil analisis thermodinamika pada motor bakar 6-langkah tipe-5 menggunakan siklus MUB-5 dibandingkan dengan motor bakar 4-langah mengalami kenaikan efisiensi termal rata-rata sebesar 14,58\%.

\section{DAFTAR PUSTAKA}

[1] BADAN PUSAT STATISTIK,. "Perkembangan Jumlah Kendaraan Bermotor Menurut Jenis". Jakarta: BPS. https://www.bps.go.id/linkTableDinamis/view/id/1133. Diakses: 21 Februari 2019.

[2] SOEDOMO, M., SURIHANTO, I., MAXDONI \& H. TOKKONG., "Pengukuran Emisi Pencemaran Udara Bersumber dari Lalu Lintas Perkotaan, Inventarisasi dan Identifikasi”. Laporan Penelitian. Bandung: ITB., 1983.

[3] SAEPUDIN, A., ADMONO, T., "Kajian Pencemaran Udara Akibat Emisi Kendaraan Bermotor di DKI Jakarta”, Jurnal Teknologi Indonesia, v. 28, n.2, pp. 29-39, 2005.

[4] MIQDAD, RAZAN., "Pengaruh Campuran Bahan Bakar Gasoline-Ethanol (Gasohol) Terhadap Emisi Gas Buang Motor Bakar Otto 6 langkah". Skripsi, Tidak Dipublikasikan, Malang: Universitas Brawijaya, 2018.

[5] NURAMAL, A., PUSPAWAN, A., RESWANTO., “Analisa Pengaruh Variasi Profil Camshaft Standar Dan Modifikasi Pada Gerakan Penutupan Katup Masukterhadap Torsi, Daya Dan Spesifik Konsumsi Bahan Bakar Mesin Siklus Otto Dengan Pendekatan Siklus Atkinson”, Jurnal Ilmiah Bidang Sains Teknologi Murni Disiplin dan Antar Disiplin, v. 2, n.14,, pp. 57-66, 2014.

[6] ARISMUNANDAR., W., "Penggerak Mula : Motor Bakar Torak", ITB, 2005.

[7] HEYWOOD, JOHN., "Ideal models of engine cycle", in: Duffy, A., Morriss, J.M., (eds), Internal Combustion Engine Fundamentals, 1 st., chapter 5, New York, McGraw-Hill Book, 1988.

[8] BAJUlAZ, ROGER., "Internal Combustion Engine", United State Patent Office, Patent No. 4,809,511., Maret 1989.

[9] CIESIOLKIEWICZ, A., MEZYK, P., “Double Pistons Internal Combustion Engine”. Journal of KONES Internal Combustion Engines, no. 1-2, ISSN 1231-4005, Patent No. 350472. Warsaw, Poland: RP Patent Office, november 2001.

[10] ZIAB AZMI, A., "Six Stroke Engine With Intake - Exhaust Valves", United State Patent Office, Patent No. US 6,789,513 B2, september 2014.

[11] SISWANTO, E., WIDODO, A.S., HAMIDY, N., WIDHIYANURIYAWAN, D., NOOR, G.R.F., "Effect Of Venturi Diameter Of Carburetor On Performance Of Six-Stroke 125 Cc Combustion Engine”, Journal of Environmental Engineering \& Sustainable Technology, v. 03, n. 02, pp. 16-22. 2016.

[12] SISWANTO, E. “Metode Operasi Motor Pembakaran Dalam Siklus Enam Langkah". IDP000040589. 2016. 
[13] SISWANTO, E., WIDHIYANURIYAWAN, D., WIDODO, A.S., HAMIDI, N., DARMADI, D.B., and SUDJITO., "On The Performance Of Six-Stroke Single-Power Combustion Engine", JP Journal of Heat and Mass Transfer, v. 14, n. 2, pp. 201-218, 2017.

[14] NINGRAT, A.A.W.K.., KUSUMA, I.G.B.W., , ADNYANA, I.W.B., "Pengaruh Penggunaan Bahan Bakar Pertalite Terhadap Akselerasi Dan Emisi Gas Buang Pada Sepeda Motor Bertransmisi Otomatis", Jurnal Mettek, v. 2, n. 1, pp. 59-67, 2016.

[15] RAZI, M., SISWANTO, E., WIJAYANTI, W., "Pengaruh derajat pengapian terhadap kinerja motor bakar 6 langkah berbahan bakar etanol”, Jurnal Rekayasa Mesin, v. 10, n. 3, pp. 299-308. 2019. 